\title{
Inhalt, Vol. 1, No. 6, 1978
}

\section{Contents}

Impressum Ill

Busse, E. und Rose, H., Berlin, DDR

Verhältnis von cyclo-3':5'-Adenosinmonophosphat zu

cyclo-3': 5'-Guanosinmonophosphat in menschlichen Tu-

morgeweben 221

Buchbesprechungen 224

Locher, P. und Nagel, G. A., Basel

Zum psychologischen Verhalten infektgefährdeter Pa-

tienten unter Isolierbedingungen $\quad 226$

Truss, F., Göttingen

Die operative Behandlung maligner Hodengeschwülste . 234

Solassol, Cl. und Joyeux, H., Montpellier

Künstlicher Gastrointestinaltrakt bei Magen-Darm-

Krebs 239

Mayr, A. C, St. Gallen

Chemotherapie gastrointestinaler Tumoren (Literatur-

übersicht) 248

Buhner, R. und Gottschalk, R., Heidelberg

Neuere Methoden in der Früherkennung einer durch

Adriamycin induzierten Kardiomyopathie 258

Salzer, G. und Havelec, L., Wien Rezidivprophylaxe bei operierten Bronchuskarzinom-patienten mit dem Mistelpräparat Iscador ${ }^{\circledR}$ - Ergebnisse eines klinischen Versuchs aus den Jahren 1969-

$1971 \ldots 264$

Imprint Ill

Busse, E. and Rose, H., Berlin, GDR

Ratio of Cyclic-3':5'-Adenosine Monophosphate to

Cyclic-3':5'-Guanosine Monophosphate in Human Tu

mor Tissues 221

Book Reviews 224

Locher, P. and Nagel, G. A., Basel

Psychological Reactions of Patients to Reverse and

Germ-free Isolation Conditions 226

Truss, F., Göttingen

Surgical Treatment of Malign Testicular Tumors

Solassol, Cl. and Joyeux, H., Montpellier

Artificial Gut in Gastrointestinal Cancer

Mayr, A. C, St. Gallen 
Chemotherapy of Gastrointestinal Cancer (Literature Survey) 248

Buhner, R. and Gottschalk, R., Heidelberg

Recent Trends in Early Recognition of Adriamycin-in-

duced Cardiomyopathy 258

Salzer, G. and Havelec, L., Vienna

The Mistletoe Preparation Iscador ${ }^{\circledR}$ as an Anti-recur rence Prophylactic Agent in the Treatment of Operated

Carcinoma of the Bronchial Tree - Clinical Results of a

Study Performed 1969-1971 264

Bibliographischer Hinweis: Inhaltsverzeichnisse dieser Zeitschrift erscheinen regelmäßig in current contents ${ }^{\circledR}$ sowie in anderen bibliographischen Diensten. 